\title{
The Power of Manager and Executive Compensation--Evidence from China Real Estate Industry
}

\author{
Hu Liu ${ }^{1}$ and Fangfang Zhao ${ }^{2, a}$ \\ ${ }^{1}$ School of International Business, Shaanxi Normal University, Xi'an 710119, China, \\ ${ }^{2}$ School of International Business, Shaanxi Normal University, Xi'an 710119, China. \\ a1794964723@qq.com
}

Keywords: Real Estate Company; executive compensation; managerial power.

\begin{abstract}
Executive compensation has always been the focus of social and academic research. In order to study the astronomical remuneration phenomenon appears in Chinese listed companies, this paper chooses the data of A-share real estate listed companies from Shanghai and Shenzhen Stock Market from 2014-2016 as the research object, using the quintile regression method to explores the relationship between managerial power and executive compensation in Chinese real estate companies and found that the greater the power of management, the higher the executive's compensation, that is, there is a significant positive correlation between management power and executive compensation.
\end{abstract}

\section{Introduction}

The separation of ownership and management rights, and the asymmetry of the information between shareholders and management, leads to the agent problem between shareholders and managers, which results the enterprise must pay the corresponding compensation to the executives, and the optimal contract is recognized the best way to solve the problem. However, the compensation contract is also flawed because it cannot give a reasonable explanation why astronomical executive compensation occurred and its effectiveness has been questioned. When scholars in search for the reasons behind it, and they find that managerial power can influence the formulate progress of compensation, which can give a reasonable explanation of abnormal executive compensation, but the literature in supporting the theory of managerial power is less. Whether it can really play a role in explaining the astronomical compensation also needs to be further studied, which is not only the needs of development of disciplinary theory, but also the need of management innovation practice.

\section{Literature}

Most of the early research on executive compensation is about how the firm scale and performance affect executive compensation. Recently, scholars have begun to focus on the impact of executive power on executive compensation. The prevailing view is that management will use the power to manipulate compensation and improve their own interests through a variety of ways, but not all executives run an earnings management based on this purpose. Compared with the management who has much power, and the less powerful management may be able to run a surplus management [1].Bebchuk and Fried(2004)put forward the theory of managerial power[2].Otten (2008) selected 451 companies from 17countries,and chosen their compensation contract during 2001-2004 as the study object, proved the universality of managerial power theory[3].But Murphy(2002) based on the manager's market assumptions proposed that the compensation is determined by the manager's external appointment, ability and other factors rather than attributed entirely to managerial power, and the theory of managerial power is questioned[4].There are few studies on the relationship between the executive compensation and managerial power in China. Zhang Biwu(2005) pointed out that if the executive power is too large, and the supervisory role of the boards will be greatly weakened so that the executives may use their own rights to affect the formulation of their compensation[5].Gao Wenliang(2011 found that the executives' compensation of managerial 
power-based firms is higher than that of non-managerial power enterprises[6].Gong Young'un(2016) and other scholars build a comprehensive managerial power indicators with the entropy weight method studied the relationship between the power and executive compensation, and found that executive compensation and managerial power is positively related, and it means that the greater the managerial power, the higher the level of executive compensation[7].Ren Guangqian(2016)examined the effect of managerial power on executive compensation empirically and explored the conduction effect of pay benchmark between them, and the results show that managerial power and salary benchmarks is positively related to executive compensation so that executives can use their power to influence the development of compensation benchmarks to achieve the purpose of improve their own compensation [8].

\section{Theoretical Background and Hypotheses}

Bebchuk and Fried (2004) has proposed two theories about executive compensation, one is the optimal contract theory, and the other is the theory of managerial power. The former believes that if the board is controlled by the shareholders, and then the manager's remuneration will be designed according to the principle of maximizing shareholder value, while the latter argues that, in reality, the relationship between the board and the executive is not as harmonious as the expected by the optimal contract theory. And because of the existence of managerial power, the board of directors cannot play a strong impact on the managers' compensation designation and implementation, and they even standing on a front line with executives so that managers will through their own power to influence or even determine their own compensation[9].Especially when executives have a strong influence in the enterprise, they will play a key role in the formulation of the compensation contract, and then the board of directors will be at a disadvantage position when they negotiate the compensation with executives, which will lead to the making process of the compensation contracts lose its fairness.

To sum up, due to the special status of executives in the company, they have a great potential to make full use of their rights to influence the board of directors and its remuneration committee to make the development of compensation more conducive to achieve the purpose of improving their own remuneration. Hence, after we have teased out many research achievements of domestic and foreign scholars in this field, the paper put forward the expected assumptions that executive compensation is positively related with managerial power, that is, the greater the managerial power, the higher the remuneration.

\section{Method}

\subsection{Sample and Data Source.}

We collect the data from the Shanghai and Shenzhen Stock Exchanges. Our initial sample consists of 134 firms, we exclude the listed firms which are ST, ${ }^{*}$ ST and the data is incomplete, and at last the effective sample are 111 firms. The data is mainly collecting from the WIND database, He Xin Web and the annual report of the sample firms.

\subsection{Variable Definition and Descriptions.}

Dependent variable. Our dependent variable is executive compensation. In the general, compensation includes two types, namely equity incentive compensation and monetary remuneration. Given the desirability of the data, we select the executive's monetary compensation to measure executive compensation, using the sum of the highest remuneration of the top three executives as criteria, and takes the natural logarithm as the proxy variable of the index, we code executive compensation as Lay.

Independent variables. Our independent variable is managerial power. On the basis of the existing literature, this paper take a comprehensive managerial power indicators to measure it. The higher the comprehensive indicator value is, the greater the managerial power is. We coded the comprehensive managerial power indicators as Com_ power. 
Control variables. In order to ensure the rationality of the test results and avoid the phenomenon of pseudo-regression, we choose board size, firm size, firm time to market, financial leverage, and the corporate growth as control variables.

\subsection{Model.}

In order to test the hypothesis proposed in this paper, this paper constructed the model as follows:

LnPayit $=\alpha 0+\beta 1$ Powerit $+\beta 2$ Broadsizeit $+\beta 3$ Firmsizeit $+\beta 4$ Firmageit $+\beta 5$ Levit $+\beta 6$ Growthit $+\varepsilon$ it

If represents the individuals, that is the real estate listed firms, $t$ represents the time, Pay it represents the itch firm's executive compensation in t year, so others, and Eit is the error term.

\section{Results}

First, the results of descriptive statistics shows that the maximum value of executive compensation in the real estate listed companies is 15.31 million, the minimum value is 2.94 million, which indicating that there is a big difference in executive compensation from different enterprises even in the same industry. The minimum value of the overall managerial power is -0.2472 , with a maximum value of 1.3481, which indicating that in different companies, the decision-making right of the executives is different. Overall, there are significant differences between different companies in the various indicators of the real estate industry in China.

Second, the regression results are presented in Table1, it includes the OLS regression and quintile regression results between variables in the real estate companies in China. The results show that the correlation coefficient between compensation and managerial power is 0.5629 , and through the $1 \%$ significance level test, which indicating that there is a significant positive correlation between them, that is, managerial power has a significant impact on executive pay, so our hypothesis are accepted. It also confirmed empirically that with the increasing of executive power, executives have more opportunity to use their own advantages to seek personal gain. Additionally, the results also show that the firm size is significantly positive to the executive compensation $(\beta=0.3953, p<0.01)$, this is in line with the results of a lot of literature that studies the relationship between executive compensation and firm size, this is because the larger the enterprise, the more sophisticated the hierarchy, and so managers have many, burdensome and more complex work to deal with, which requires managers to have a wide range of capabilities and quality, so the company needs to provide more incentives for these executives to motivate them to make more efforts for the company. The other results in Table 1 are the quintile regression for $\mathrm{Q}=0.1, \mathrm{Q}=0.25, \mathrm{Q}=0.5, \mathrm{Q}=0.75$, and $\mathrm{Q}=0.9$. We find that managerial power has a significantly positive association with executive compensation at $\mathrm{Q}=0.1(0.4204$, with $\mathrm{p}<0.01), \mathrm{Q}=0.25(0.5732$, with $\mathrm{p}<0.01), \mathrm{Q}=0.5(0.7468$, with $\mathrm{p}<0.01), \mathrm{Q}=0.75(0.6938$, with $\mathrm{p}<0.01)$, which all passed the significance level test of $1 \%$, even at $\mathrm{Q}=0.9(0.5586$, with $\mathrm{p}<0.1)$, which also passes the $10 \%$ significance level test. On the whole, the results are consistent with the linear regression results.

Third in order to further ensure the accuracy of the conclusions, we use the logarithm of average compensation of the top three executives' compensation(lappet) in the real estate enterprises in China replaces the logarithm of the sum of the top three executives' compensation (lay) to build a robust test, and both the regression and the quintile regression results indicate that the managerial power is still significantly related to the logarithm of average compensation of the top three executives' compensation(lappet), the conclusions and the hypothesis of this paper are also validated and the hypothesis of this paper can still be proved strongly. 
Table 1. OLS and quintile regression results

\begin{tabular}{|c|c|c|c|c|c|c|}
\hline & \multirow{2}{*}{$\begin{array}{c}\begin{array}{c}\text { OLS } \\
\text { regression }\end{array} \\
\text { Robust OLS }\end{array}$} & \multicolumn{5}{|c|}{ Quintile regression } \\
\hline & & Q0.1 & Q0.25 & $\begin{array}{l}\text { Q0.5(medi } \\
\text { an) }\end{array}$ & Q0.75 & Q0.9 \\
\hline \multicolumn{7}{|l|}{ Independent variables } \\
\hline Managerial power & $0.5629 * * *$ & $\begin{array}{l}0.4204 \\
* * *\end{array}$ & $\begin{array}{l}0.5732 \\
* * *\end{array}$ & $0.7468 * * *$ & $\begin{array}{l}0.6938 \\
* * *\end{array}$ & $\begin{array}{l}0.5586 \\
*\end{array}$ \\
\hline \multicolumn{7}{|l|}{ Control variables } \\
\hline Broad size & 0.0192 & $\begin{array}{l}-0.011 \\
3\end{array}$ & $\begin{array}{l}-0.007 \\
5\end{array}$ & 0.0156 & $\begin{array}{l}0.052 * \\
* *\end{array}$ & 0.0405 \\
\hline Firm size & $0.3953 * * *$ & $\begin{array}{l}0.3099 \\
* * *\end{array}$ & $\begin{array}{l}0.3365 \\
* * *\end{array}$ & $0.3571 * * *$ & $\begin{array}{l}0.3425 \\
* * *\end{array}$ & $\begin{array}{l}0.3439 \\
* * *\end{array}$ \\
\hline Firm age & 0.0144 & 0.0047 & 0.0061 & $0.0164 * * *$ & $0.017 *$ & 0.0143 \\
\hline Lev & -0.1417 & $\begin{array}{l}-0.327 \\
6\end{array}$ & 0.231 & 0.3151 & 0.3595 & 0.3154 \\
\hline Growth & 0.0097 & 0.0318 & 0.0126 & 0.008 & $\begin{array}{l}-0.012 \\
4\end{array}$ & 0.0199 \\
\hline Constant & $3.0917 * * *$ & $\begin{array}{l}3.3793 \\
* * *\end{array}$ & $\begin{array}{l}3.1511 \\
* * *\end{array}$ & $2.9141 * * *$ & $\begin{array}{l}2.987^{*} \\
* *\end{array}$ & $\begin{array}{l}3.5518 \\
* * *\end{array}$ \\
\hline $\begin{array}{l}\mathrm{R} 2 \text { (Pseudo for quintile } \\
\text { regression) }\end{array}$ & 0.3669 & 0.177 & 0.2406 & 0.3015 & 0.3299 & 0.3067 \\
\hline
\end{tabular}

\section{Discussion and Conclusion}

Since the outbreak of the financial crisis, there has been a decline in performance, however the compensation that enterprises pay to executives did not fall but rise, which has aroused widespread concern from all sectors of society. This paper chooses the data of A-share real estate listed companies from Shanghai and Shenzhen Stock Market in China from 2014-2016 as the research object, by using the quintile regression method to explores the relationship between management power and executive compensation, and we found that there is a significant positive correlation between management power and executive compensation, that is, the greater the power of management, they have a great potential to make full use of their own rights to influence the board of directors and its remuneration committee to make the development of compensation more conducive to the interests of the executives, and then to achieve the purpose of improving their own remuneration.

The research conclusion of this paper provides an analytical perspective for the development of executive compensation incentive mechanism in China, especially for the real estate listed companies. Through the discussion, we can take the following measures to restrict the excessive managerial power. Firstly, strengthen shareholder's supervision over executives. Secondly, granting appropriate authority to the executive. Thirdly, ensuring the independence of the boards. Fourth, improving the manager market mechanism. Fifth, improving the executive compensation and incentive mechanism of listed companies.

The study of this paper may still have the following deficiencies. First, we only selected the monetary compensation as an alternative indicator of executive compensation variables and did not take the equity incentives into consideration. Second, there is no uniform standard for the selection of indicators of managerial power indicators, which should be further discussed.

\section{References}

[1]. Dow J, Repose C (2005). “Coe Compensation, Change, and Corporate Strategy.”Journal Of Finance (6),2701 -2727. 
[2]. Bebchuk. L and Fried. J (2004). Pay Without Performance: The Unfulfilled Promise Of Executive Compensation. Ma: Harvard University Press.

[3]. Often. J.A and Heavens. P (2008). "The Managerial Power Theory of Executive Pay: A Cross National Test and Extension.”Academy Of Management Best Paper Proceedings.

[4]. Murphy. K.J (2002). "Explaining Executive Compensation: Managerial Power Versus The Perceived Cost Of Options. "The University Of Chicago Law Review (3), 847 -869.

[5]. Zhang, B, W., Shi, J, T. (2005). "Board Characteristics, Executive Compensation and Salary Sensitivity -- The Empirical Analysis of Listed Companies in China. "Management Science (04), 32-39.

[6]. GAO, H, L., H, Luo. Cheng, P, X. (2011). "Managerial Power and Executive Pay Stickiness.”Economic Fabric (06), 82-86.

[7]. Gong, Y, X., Y, L, Xu. (2016). "Research on Managerial Power and Executive Compensation Behavior of Listed Companies.”Market Forum (10), 32-34.

[8]. Ren, G, Q. (2016). “Managerial Power, Pay Bench-Marking and Executive Compensation.”The Journal of Zhongnan University of Economics and Law (02), 78-85.

[9]. Aggarwal, Rajesh. K, Sam Wick, Andrew. A (1999). "Executive Compensation, Strategic Competition, and Relative Performance Evaluation: Theory and Evidence.’The Journal of Finance, 1999-2043. 